\title{
HIP SINTERING AND SATURATION MAGNETIZATION OF Fe4N
}

\author{
S. Shinmura, S. Ito and K. Akashi
}

Department of Industrial Chemistry, Faculty of Science and Technology, Science University of Tokyo, Noda, Chiba 278, Japan

\begin{abstract}
Fe}_{4} \mathrm{~N}$ powder has been sintered at below the decomposition temperature applying a hipping pressure, and the influence of oxygen content on saturation magnetization of hipped $\mathrm{Fe}_{4} \mathrm{~N}$ has been studied. The hipping temperature was restricted below $500 \mathrm{C}$, because $\mathrm{Fe}_{4} \mathrm{~N}$ was decomposed at $550^{\circ} \mathrm{C}$. The maximum relative density of $97 \%$ was obtained for the $\mathrm{Fe}_{4} \mathrm{~N}$ hipped at $500 \mathrm{C}$ under $200 \mathrm{MPa}$. The $\mathrm{Fe}_{4} \mathrm{~N}$ hipped at $450^{\circ} \mathrm{C}$ under $200 \mathrm{MPa}$ revealed the maximum saturation magnetization of $182 \mathrm{emu} / \mathrm{g}$ with a high relative density of $95 \%$. It was confirmed that the presence of oxygen decreased saturation magnetization of $\mathrm{Fe}_{4} \mathrm{~N}$. The Vickers hardness was measured as Hv5.5 $\times 10^{2}$, and the corrosion resistance was higher than that of steel.
\end{abstract}

\section{INTRODUCTION}

Several stable compounds such as $\gamma^{\prime}-\mathrm{Fe}_{4} \mathrm{~N}, \mathrm{E}-\mathrm{Fe}_{\mathbf{x}} \mathrm{N}(2<\mathrm{x}$ $\leq 1), \zeta-\mathrm{Fe}_{2} \mathrm{~N}$ are known in $\mathrm{Fe}-\mathrm{N}$ system. Among them, $\mathrm{Fe}_{4} \mathrm{~N}$ powder exhibits high saturation magnetization of $186 \mathrm{emu} / \mathrm{g}[1]$ at room temperature. This saturation magnetization is slightly lower than that of pure iron, which is calculated as $218 \mathrm{emu} / \mathrm{g}$. However, the electric resistance of $\mathrm{Fe}_{4} \mathrm{~N}$ is ten times larger than that of pure iron[2]. In addition, $\mathrm{Fe}_{4} \mathrm{~N}$ reveals excellent corrosion resistance and wear resistance, compared to pure iron. Therefore, the preparation of $\mathrm{Fe}_{4} \mathrm{~N}$ powder and the deposition of thin film have been widely studied[3-5]. The thin film is applicable to the magnetic recording head[6]. On the other hand, $\mathrm{Fe}_{4} \mathrm{~N}$ decomposes to iron and nitrogen at $670^{\circ} \mathrm{C}$ under atmospheric pressure[7]. Accordingly, it is impossible to sinter $\mathrm{Fe}_{4} \mathrm{~N}$ powder under atmospheric pressure. Thus, its shape has been limited to a powder or to a thin film. If the sintering is possible, it will be expected to use the sintered $\mathrm{Fe}_{4} \mathrm{~N}$ as a magnetic recording material.

We previously prepared HIP sintering of $\mathrm{Fe}_{4} \mathrm{~N}$ applying a hipping pressure at below the decomposition temperature[8]. The saturation magnetization of the specimen was $150 \mathrm{emu} / \mathrm{g}$, which was lower than that of $\mathrm{Fe}_{4} \mathrm{~N}$ powder (186 emu/g).

The purpose of this study is to increase the saturation mangetization of hipped $\mathrm{Fe}_{4} \mathrm{~N}$. In order to obtain such a high saturation magnetization, the influence of oxygen content on saturation magnetization of hipped $\mathrm{Fe}_{4} \mathrm{~N}$ has been studied. In addition, the hipped $\mathrm{Fe}_{4} \mathrm{~N}$ has been characterized by Vickers hardness, three point bending strength and corrosion resistance.

\section{II . EXPERIMENTAL}

Iron powder with average particle size of $5 \mu \mathrm{m}$, which was prepared from iron carbonyl, was nitrided at $500^{\circ} \mathrm{C}$ for 3 hours in an mixed gas of $\mathrm{NH}_{3} / \mathrm{H}_{2}\left(\mathrm{NH}_{3} 210 \mathrm{ml} / \mathrm{min} \mathrm{H}_{2}\right.$ $140 \mathrm{ml} / \mathrm{min}$ ) to obtain $\mathrm{Fe}_{4} \mathrm{~N}$ powder. The $\mathrm{Fe}_{4} \mathrm{~N}$ powder $(10 \mathrm{~g})$ was charged into an aluminum capsule $(35 \mathrm{~mm}, \phi$ $11 \mathrm{~mm}$ ) applying uniaxial pressure of $160 \mathrm{MPa}$. The process was carried out in a dried nitrogen atmosphere. Then, the sealed capsule was hipped at $450-550^{\circ} \mathrm{C}$ for 2 hours under 50-200 MPa.

The hipped $\mathrm{Fe}_{4} \mathrm{~N}$ was identified by XRD. The relative density of hipped $\mathrm{Fe}_{4} \mathrm{~N}$ was measured by Archimedes' method. The saturation magnetization of hipped $\mathrm{Fe}_{4} \mathrm{~N}$ was measured by a vibrating sample magnetometer in an applied field up to 7kOe at room temperature. The Vickers hardness was measured with $10 \mathrm{gf}$. The three point bending strength was measured for the specimen with a size of $5 \mathrm{~mm} \times 5 \mathrm{~mm}$ $\times 20 \mathrm{~mm}$. The corrosion resistance was evaluated by measuring a corrosion current density in water.

\section{III . REsUlts AND Discussion}

Figure 1 shows the XRD patterns for hipped $\mathrm{Fe}_{4} \mathrm{~N}$. The hipped specimens obtained at $450^{\circ} \mathrm{C}$ and $500^{\circ} \mathrm{C}$ under 50MPa were identified as single-phase $\mathrm{Fe}_{4} \mathrm{~N}$. Small iron peaks were detected in the XRD pattern of the specimen hipped at $550^{\circ} \mathrm{C}$. However, by the application of $200 \mathrm{MPa}$, the iron peaks were slightly suppressed even at $550^{\circ} \mathrm{C}$. Therefore, hipping temperature was limited at below $500 \mathrm{C}$ to prevent the decomposition of $\mathrm{Fe}_{4} \mathrm{~N}$.

Figure 2 shows the relative densities of hipped $\mathrm{Fe}_{4} \mathrm{~N}$. 


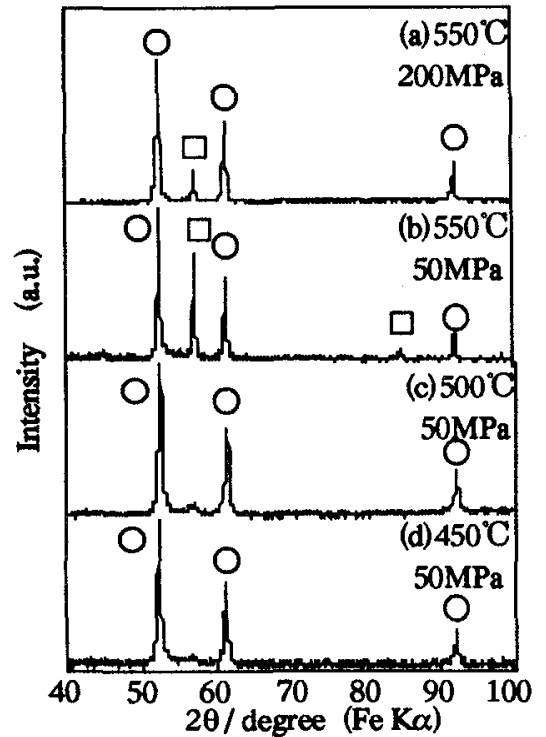

Fig. 1. XRD patterns for hipped $\mathrm{Fe}_{4} \mathrm{~N}$. $\mathrm{O} \mathrm{Fe}_{4} \mathrm{~N} \quad \square \mathrm{Fe}$

Hipping pressure largely affected the sintering densities of $\mathrm{Fe}_{4} \mathrm{~N}$. The sintering densities of $\mathrm{Fe}_{4} \mathrm{~N}$ obtained at $450^{\circ} \mathrm{C}$ were slightly smaller than those obtained at $500^{\circ} \mathrm{C}$ in the whole range of hipping pressure $(50-200 \mathrm{MPa})$. The maximum relative density of $97 \%$ was obtained in the $\mathrm{Fe}_{4} \mathrm{~N}$ hipped at $500^{\circ} \mathrm{C}$ under $200 \mathrm{MPa}$. The dense microstructure was also confirmed by scanning electron microscope.

Figure 3 shows the saturation magnetizations of $\mathrm{Fe}_{4} \mathrm{~N}$. The $\mathrm{Fe}_{4} \mathrm{~N}$ obtained at $450^{\circ} \mathrm{C}$ exhibited higher saturation magnetizations than those obtained at $500^{\circ} \mathrm{C}$. The $\mathrm{Fe}_{4} \mathrm{~N}$ specimens obtained under 200MPa showed high saturation magnetizations compared to those obtained under lower pressure. The maximum saturation magnetization $182 \mathrm{emw} / \mathrm{g}$

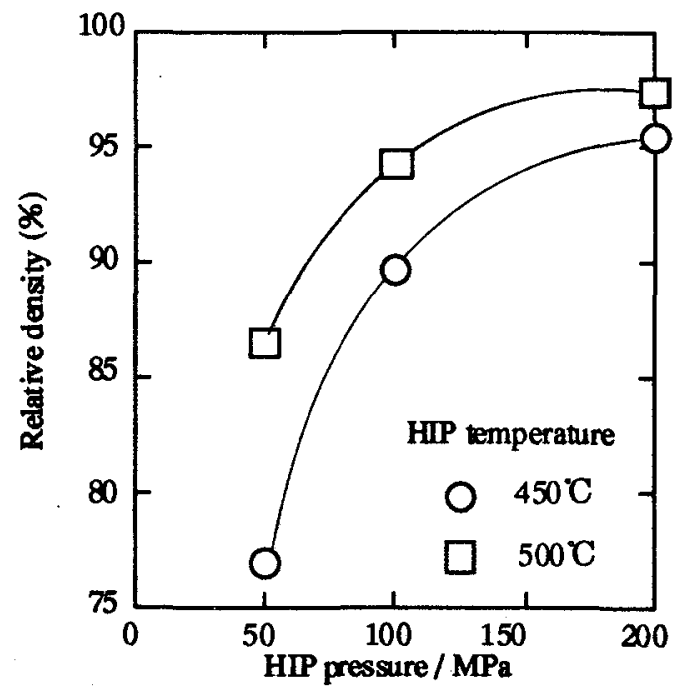

Fig.2 Relative densities of hipped $\mathrm{Fe}_{4} \mathrm{~N}$

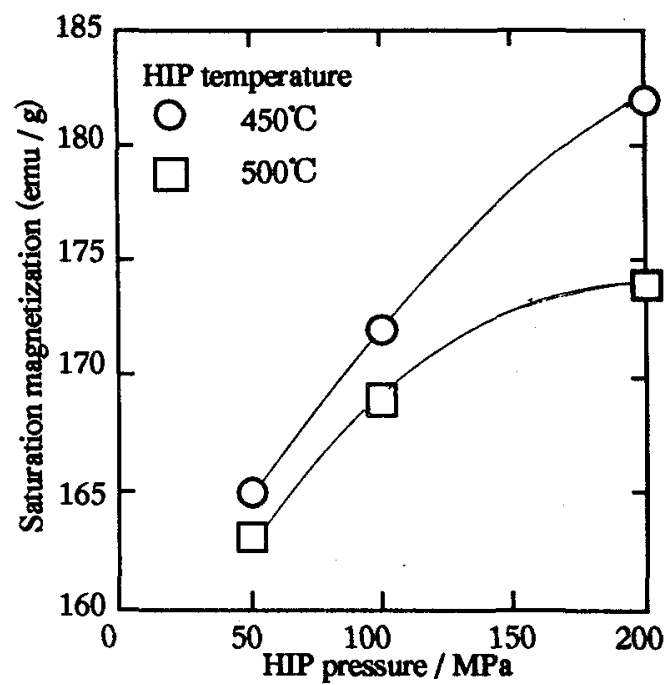

Fig.3 Saturation magnetizations of hipped $\mathrm{Fe}_{4} \mathrm{~N}$ measured at room temperature.

was obtained for the $\mathrm{Fe}_{4} \mathrm{~N}$ hipped at $450^{\circ} \mathrm{C}$ under $200 \mathrm{MPa}$. This saturation magnetization is higher than that in the previous paper $(150 \mathrm{emu} / \mathrm{g})$, and is approximately same as that of $\mathrm{Fe}_{4} \mathrm{~N}$ powder (186emu/g).

Nakajima et al. reported that in a hot pressed $\mathrm{Fe}_{4} \mathrm{~N}$ with relative density of $79.9 \%$, low saturation magnetization of $\mathrm{Fe}_{4} \mathrm{~N}$ was caused by $\mathrm{Fe}_{3} \mathrm{O}_{4}, \mathrm{Fe}_{2} \mathrm{~N}$ and austenite in $\mathrm{Fe}_{4} \mathrm{~N}[9]$. Therefore, $\mathrm{H}_{2} \mathrm{O}$ was added to oxidize the $\mathrm{Fe}_{4} \mathrm{~N}$ powder, and the influence of oxygen content was studied. The hipped specimens including oxygen were determined as the single phase of $\mathrm{Fe}_{4} \mathrm{~N}$ by XRD. The dependence of oxygen content on the saturation magnetization is shown in Fig. 4. By the addition of small amount of oxygen (0.33\%) to $\mathrm{Fe}_{4} \mathrm{~N}$ raw powder, the saturation magnetization was decreased to $157 \mathrm{emw} / \mathrm{g}$. It was confirmed that the presence of oxygen decreased saturation magnetization of $\mathrm{Fe}_{4} \mathrm{~N}$. The low satu-

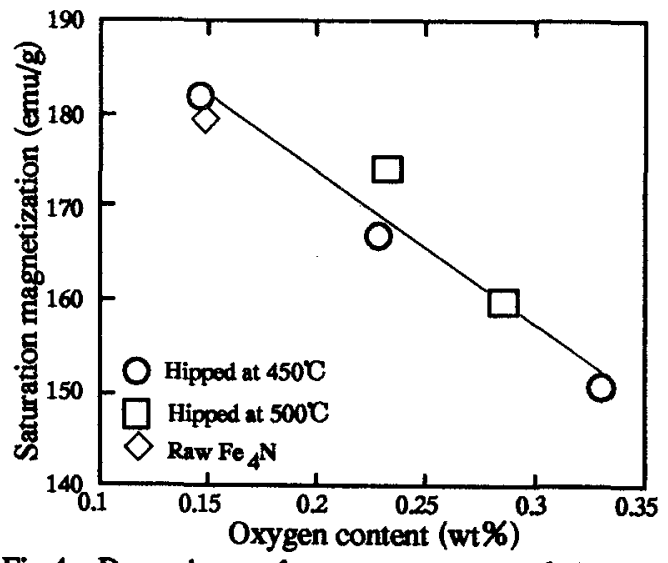

Fig.4 Dependence of oxygen content on the saturation magnetization of hipped Fes $\mathrm{N}$ under $200 \mathrm{MPa}$. 


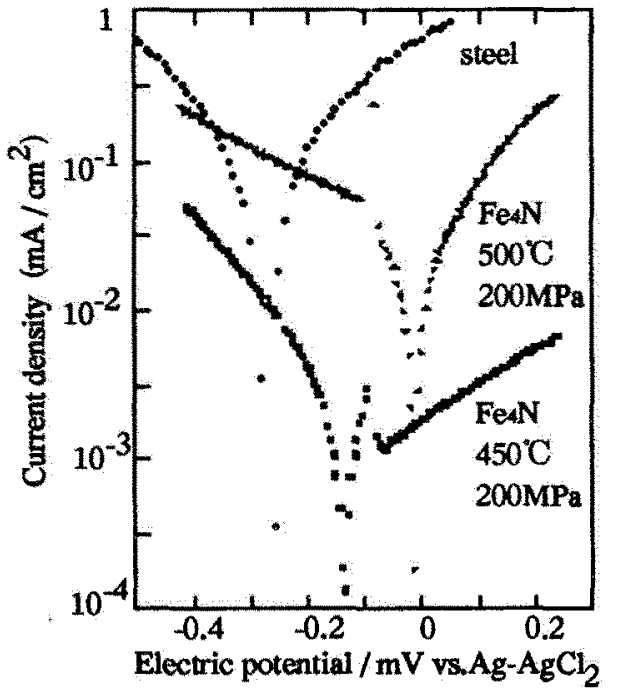

Fig.5 Polarization curves of hipped $\mathrm{Fe} 4 \mathrm{~N}$ and steel(SS400). (in water, pH 7)

ration magnetization in the previous paper may be due to the presence of oxygen.

The Vickers hardness of $\mathrm{Fe}_{4} \mathrm{~N}$ hipped at $450^{\circ} \mathrm{C}$ under $200 \mathrm{MPa}$ was $\mathrm{Hv} 5.5 \times 10^{2}$, which is higher than that of pure iron $\left(2 \times 10^{2}\right)$. The three point bending strength of the $\mathrm{Fe}_{4} \mathrm{~N}$ hipped at $450^{\circ} \mathrm{C}$ under $200 \mathrm{MPa}$ was $3 \times 10 \mathrm{~kg} / \mathrm{mm}^{2}$. This strength is comparable to that of Sialon $(3.3 \times 10 \mathrm{~kg} /$ $\mathrm{mm}^{2}$ )[10] sintered under atmospheric pressure. Figure 5 shows polarization curves of hipped $\mathrm{Fe}_{4} \mathrm{~N}$ and $\mathrm{SS} 400$. The hipped $\mathrm{Fe}_{4} \mathrm{~N}$ revealed excellent corrosion resistance, compared to steel(SS400). The strength and corrosion resistance of hipped $\mathrm{Fe}_{4} \mathrm{~N}$ may be enough to use as a magnetic recording material.

\section{IV . CONCLUSIONS}

The $\mathrm{Fe}_{4} \mathrm{~N}$ hipped at $450^{\circ} \mathrm{C}$ under $200 \mathrm{MPa}$ revealed the maximum saturation magnetization of $182 \mathrm{emu} / \mathrm{g}$ with a high relative density of $95 \%$. The oxygen content of $\mathrm{Fe}_{4} \mathrm{~N}$ largely influenced on the saturation magnetization of $\mathrm{Fe}_{4} \mathrm{~N}$.
Vickers handness of the hipped $\mathrm{Fe}_{4} \mathrm{~N}$ was $\mathrm{Hv} 5.5 \times 10^{2}$, and the corrosion resistance was higher than that of steel.

\section{ACKNOWLEDGMENTS}

Authors are very grateful to Prof. N. Hiratsuka for many useful discussions and measuring saturation magnetization. Authors would also like to thank Dr. T. Yoshioka for measuring oxygen content. The polarization curve was measured with the useful suggestion of Prof. I. Sekine.

\section{REFERENCES}

[1]G. Shirane, W. J. Takei and S. L. Ruby, Phys. Rev., vol.126. pp. 49-52, 1962.

[2]S. K. Chen, S. Jin, G. W. Kammlott, T. H. Thefel, D. W. Johnson Jr. and E. M. Gyorgy, J. Mag. Mag. Mater., vol.110. pp. 65-72. 1992.

[3]Z. X. Tang, G. C. Hadjipanayis, S. I. Shah, V. Papaefthymiou and K. J. Klabunde, J. Mag. Mag. Mater., vol119. pp.49-53. 1993.

[4]K. Umeda, Y. Kawashimo, M. Nakasone, S. Harada and A. Tasaki, Jpn. J. Appl. Phys., vol.23. pp. 1576-1579. 1984. [5]A. Morisako, K. Takahashi and M. Matsumoto, J. Appl. Phys., vol.63[8], pp. 3230-3232, 1988.

[6]N. Kitaori, M. Shinoda, S. Arikawa and H. Ogawa, DENKIKAGAKU, pp. 936, 1987.

[7]K. H. Jack, Proc. Roy. Soc. London, vol.A208, pp. 200, 1948.

[8]J. Hirose, S. Ito, K. Akashi and N. Koura, J. Jpn. Soc. Powder and Powder Metallurgy, vol.41[8], pp. 989-993, 1994.

[9]K. Nakajima, K. Taki, M. Takata and S. Okamoto, J. Ceramic Soc. Jpn, vol. 99[4], pp. 311-314, 1991.

[10]W. J. Arrol, "Ceramics for High Performance Applications, " ed. J.J. Burke et al, Brook Hill Pub, Co, p. 729, 1975. 